\title{
Effect of Energy Levels of Diets Formulated on Total or Digestible Amino Acid Basis on Broiler Performance
}

\section{Author(s)}

Maiorka A

Dahlke $F^{1}$

Santin $\mathrm{E}^{1}$

Kessler $\mathrm{AM}^{2}$

Penz Jr. AM ${ }^{2}$

Universidade Federal do Paraná

2 Universidade Federal do Rio Grande do Sul

Faculdade de Agronomia

\section{Mail Address}

Alex Maiorka

Rua dos Funcionários 1540

Departamento de Zootecnia

80.035-050 - Curitiba, PR.

E-mail: amaiorka@ufpr.br

\section{ABSTRACT}

This study was conducted to evaluate the performance and carcass and breast yields of broilers fed two different energy levels $(3,200$ or $2,900 \mathrm{kcal} \mathrm{ME} / \mathrm{kg}$ ) and two ways of expressing amino acid requirements (total - TAA or digestible - DAA) between 21 and 42 days of age. The results showed that broilers fed the diet containing 3,200 kcal ME/kg had higher weight gain $(P=0.015)$, better feed conversion ( $P=0.001)$, and higher abdominal fat deposition $(P=0.001)$ as compared to those fed the diet containing 2,900 kcal ME/kg. Diets formulated on DAA basis promoted higher weight gain ( $P=0.043)$, better feed conversion $(P=0.010)$ and better conversion of ME intake into weight gain $(P=0.007)$ as compared to those formulated on TAA basis. The results of this study suggest that formulation based on DAA is necessary if the diets contain protein sources that are not reliable in terms of amino acid digestibility. The response to formulation based on DAA was minimized when birds received the low energy level diet $(2,900 \mathrm{kcal} \mathrm{ME} / \mathrm{kg})$.

\section{INTRODUCTION}

In the past, poultry diets were formulated to meet crude protein requirements. However, the growth of the synthetic amino acid industry permitted the reduction of crude protein levels in diets and nutritionists were then able to formulate diets considering the specific requirements of essential amino acids. Recent studies show the importance of formulation based on digestible amino acids (DAA), as well as of amino acid balance, for optimal performance and reduction of environmental contamination due to better use of the protein of the diet and lower amount of nitrogen in the excreta (Baker \& Han, 1994; Rostagno et al., 1995; Dari \& Penz, 1996).

The wide variation in the composition and the amount of protein and/or amino acids present in animal byproducts is of great concern when using these raw materials. Protein quality and amino acid digestibility of these byproducts depend primarily on processing temperature, cooking time and drying process, which vary according to the processing system.

The excess of energy intake is related to the calorie:protein $(C: P)$ ratio in the diet, and consequently, to carcass composition. In isocaloric diets, if crude protein level is decreased, there is an increase in $\mathrm{C}: \mathrm{P}$ ratio, which result in fatter carcasses (Summers et al., 1965; Griffiths et al., 1977; Rosebrough \& Steele, 1985).

This study was conducted to evaluate the live performance and carcass composition of broilers fed diets with two energy levels (3,200 or 2,900 $\mathrm{kcal} \mathrm{ME} / \mathrm{kg}$ ) and two ways to express amino acid requirements, either as total amino acid (TAA) or digestible amino acid (DAA). 


\section{MATERIALS AND METHODS}

A total of 200 male Ross chicks was used. During the starter phase ( 1 to 18 days of age), chicks were housed in a commercial broiler house and fed according to the requirements proposed by the National Research Council (NRC, 1994). At 18 days of age, birds were individually weighed, selected by weight and transferred to a room equipped with cages, measuring $80 \times 35$ $\mathrm{cm}$. Broilers were submitted to a 3-day period of adaptation to the new environment, since housing was changed from a poultry-house with wood shavings litter to wired-floor cages. Water and feed were also supplied ad libitum. The lighting regimen was continuous, with 24 hours of light daily, throughout the experimental periods.

It was used two energy levels $(2,900$ and 3,200 kcal $\mathrm{ME} / \mathrm{kg}$ of diet) and two forms of expressing amino acid requirements (TAA and DAA), in the ratio recommended by researchers of the University of Illinois, USA, for ideal protein for broilers. The total amino acid values of the ingredients were assayed by high-pressure liquid chromatography analysis. In order to determine digestibility, the levels of TAA determined in the analysis were multiplied by their respective digestibility coefficients, as determined by Heartland Lysine (1995). Therefore, the following treatments were applied: diet with 2,900 kcal ME/kg, formulation based on TAA; diet with 2,900 kcal ME/kg, formulation based on DAA; diet with 3,200 kcal ME/kg, formulation based on TAA; diet with 3,200 kcal ME/kg, formulation based on DAA.

Diets were formulated based on corn and soybean meal, in which amino acids are highly digestible, and on meat meal, wheat middling, and feather meal, in which amino acids have low digestibility. Diets are shown on Table 1. Diets were fed in mash form with mean geometric diameter of $850 \mathrm{~m}$.

During the experimental period, feed intake, metabolizable energy intake, weight gain and feed conversion were measured. In order to evaluate carcass quality, at the end of the experimental period (42 days of age), 2 birds with body weights as close as possible to the average body weight of the experimental unit were slaughtered per repetition. These birds were weighed, defeathered, eviscerated, and weighed again to obtain carcass weight (including head and feet),

\begin{tabular}{|c|c|c|c|c|}
\hline Ingredient (\%) & $\begin{array}{c}2,900 \mathrm{kcal} \\
\mathrm{ME} / \mathrm{kg}, \mathrm{TAA}\end{array}$ & $\begin{array}{l}2,900 \mathrm{kcal} \\
\mathrm{ME} / \mathrm{kg}, \text { DAA }\end{array}$ & $\begin{array}{c}3,200 \mathrm{kcal} \\
\mathrm{ME} / \mathrm{kg}, \mathrm{TAA}\end{array}$ & $\begin{array}{c}3,200 \mathrm{kcal} \\
\mathrm{ME} / \mathrm{kg} \text {, DAA }\end{array}$ \\
\hline Yellow corn & 62.36 & 62.36 & 62.36 & 62.36 \\
\hline Soybean meal 44 & 14.72 & 14.72 & 14.72 & 14.72 \\
\hline Meat and bone meal & 5.00 & 5.00 & 5.00 & 5.00 \\
\hline Wheat bran & 5.00 & 5.00 & 5.00 & 5.00 \\
\hline Feather meal & 5.00 & 5.00 & 5.00 & 5.00 \\
\hline Soybean oil & 2.17 & 2.17 & 5.57 & 5.57 \\
\hline Oyster shell & 0.86 & 0.86 & 0.86 & 0.86 \\
\hline Mineral and vitamin mix ${ }^{1}$ & 0.26 & 0.26 & 0.26 & 0.26 \\
\hline Salt & 0.24 & 0.24 & 0.24 & 0.24 \\
\hline Dicalcium Phosphate & 0.12 & 0.12 & 0.12 & 0.12 \\
\hline L-Threonine & 0.00 & 0.04 & 0.00 & 0.04 \\
\hline L-Lysine-HCl & 0.21 & 0.23 & 0.21 & 0.23 \\
\hline DL-Methionine & 0.06 & 0.10 & 0.06 & 0.10 \\
\hline Kaolin & 4.00 & 3.90 & 0.60 & 0.50 \\
\hline \multicolumn{5}{|c|}{ Calculated Analysis } \\
\hline Crude protein (\%) & 20.0 & 20.0 & 20.0 & 20.0 \\
\hline $\mathrm{ME}(\mathrm{kcal} / \mathrm{kg})$ & 2,900 & 2,900 & 3,200 & 3,200 \\
\hline Calcium (\%) & 0.90 & 0.90 & 0.90 & 0.90 \\
\hline Available phosphorus (\%) & 0.35 & 0.35 & 0.35 & 0.35 \\
\hline Total sulphur amino acids (\%) & 0.81 & - & 0.81 & - \\
\hline Digestible sulphur amino acids (\%) & - & 0.67 & - & 0.67 \\
\hline Total lysine (\%) & 1.07 & - & 1.07 & - \\
\hline Digestible lysine (\%) & - & 0.89 & - & 0.89 \\
\hline Total threonine (\%) & 0.74 & - & 0.74 & - \\
\hline Digestible threonine (\%) & - & 0.64 & - & 0.64 \\
\hline $\mathrm{Na}(\%)$ & 0.18 & 0.18 & 0.18 & 0.18 \\
\hline
\end{tabular}


breast weight and abdominal fat weight. Carcass yield was determined as the carcass weight in relation to body weight, and expressed as percentage of body weight (\%), whereas breast yield (with bone) and abdominal fat were expressed as percentages of the carcass weight.

A completely randomized experimental design was used, in a factorial scheme $(2 \times 2)$. The experimental unit consisted of a cage with 10 birds, with 5 replicates per treatment, with a total of 20 cages. Data were submitted to analysis of variance and Scheffé's test to determine contrasts among treatments using the General Linear Model (GLM) procedure of SAS (1998).

\section{RESULTS AND DISCUSSION}

Feed intake was not significantly influenced by the way amino acid requirements were expressed, which is consistent with previously published results from experiments comparing diets based on alternative ingredients with low amino acid digestibility to diets based on ingredients with high amino acid digestibility (corn and soybean meal), and to diets with low digestibility ingredients supplemented with synthetic amino acids (Rostagno et al., 1995; Dari \& Penz, 1996). The formulation based on total or digestible amino acids did not influence metabolizable energy intake. In addition, feed intake was not influenced by dietary energy level. However, metabolizable energy intake was higher in birds fed diets containing 3,200 kcal ME/kg $(P=0.001)$. This may be explained by the fact that the diet with 3,200 kcal ME/kg merely promoted a trend to reduce feed intake ( $P=0.101)$. Therefore, if feed intake was similar in both diets, it was expected that diets with higher metabolizable energy would result in higher energy intake during the experimental period (Table 2).

Diet formulation based on DAA resulted in better weight gain and feed conversion, which agrees with results published by Fernandes et al. (1985), Rostagno et al. (1995) and Dari \& Penz, 1996. Diets with higher metabolizable energy level $(3,200 \mathrm{kcal} \mathrm{ME} / \mathrm{kg})$ also promoted higher weight gain and better feed conversion; these results agree with those published by Sizemore \& Siegel (1993) and Leeson et al. (1996).

The evaluation of the contrasts showed that the effects of the formulation based on DAA were significant only when diets contained the high energy level. The diet with 3,200 kcal ME/kg and DAA promoted higher weight gain as compared to the diet with 3,200 kcal ME/kg and TAA. When low energy diets were considered, the result of the formulation based on DAA was not different from that obtained with the

Table 2 - Feed intake, body weight gain, feed conversion and metabolizable energy intake.

\begin{tabular}{|c|c|c|c|c|c|}
\hline Aminoacid (AA) & ME (kcal/kg diet) & Feed intake (g) & Body weight gain (g) & Feed conversion $(g / g)$ & ME intake (kcal) \\
\hline Total & 2,900 & 3,278 & 1,462 & 2,244 & 9,506 \\
\hline Digestible & 2,900 & 3,247 & 1,472 & 2,208 & 9,416 \\
\hline Total & 3,200 & 3,222 & 1,486 & 2,166 & 10,310 \\
\hline Digestible & 3,200 & 3,168 & 1,596 & 1,986 & 10,138 \\
\hline \multicolumn{6}{|c|}{ Main effects } \\
\hline Total AA & & 3,250 & 1,474 & 2,205 & 9,908 \\
\hline Digestible AA & & 3,208 & 1,534 & 2,097 & 9,777 \\
\hline $2,900 \mathrm{kcal} \mathrm{ME} / \mathrm{kg}$ & & 3,262 & 1,467 & 2,226 & 9,416 \\
\hline 3,200 kcal ME/kg & & 3,195 & 1,541 & 2,076 & 10,224 \\
\hline \multicolumn{6}{|c|}{ Probability } \\
\hline AA & & 0.292 & 0.043 & 0.010 & 0.285 \\
\hline Energy & & 0.101 & 0.015 & 0.001 & 0.001 \\
\hline AA*Energy & & 0.775 & 0.090 & 0.071 & 0.734 \\
\hline
\end{tabular}

Table 3 - Contrasts for feed intake, body weight gain and feed conversion.

\begin{tabular}{|c|c|c|c|}
\hline Contrasts & Feed intake (g) & Body weight gain (g) & Feed conversion $(\mathrm{g} / \mathrm{g})$ \\
\hline 2,900 DAA $\times 2,900$ TAA & $3,247 \times 3,278$ & $1,472 \times 1,462$ & $2,208 \times 2,244$ \\
\hline 3,200 DAA $\times 3,200$ TAA & $3,168 \times 3,222$ & $1,596 \times 1,486$ & $1,986 \times 2,166$ \\
\hline 2,900 DAA $\times 3,200$ TAA & $3,247 \times 3,222$ & $1,472 \times 1,486$ & $2,208 \times 2,166$ \\
\hline \multicolumn{4}{|c|}{ Probability } \\
\hline 2,900 DAA $\times 2,900$ TAA & 0.580 & 0.787 & 0.503 \\
\hline 3,200 DAA $\times 3,200$ TAA & 0.343 & 0.012 & 0.003 \\
\hline 2,900 DAA x 3,200 TAA & 0.652 & 0.722 & 0.436 \\
\hline
\end{tabular}


formulation based on TAA (Table 3). These results suggest that, in the combination of low energy and DAA, energy was not sufficient to allow the expression of DAA-based formulation into growth with the same intensity as the combination of high energy and DAA. It was also found that there were no differences in weight gain among the low-energy diet based on DAA and the high-energy diet based on TAA (Table 2).

Contrasts showed that feed conversion was similar for the low-energy diet based on DAA and the lowenergy diet based on TAA. However, feed conversion promoted by the high-energy diet formulated on DAA basis was significantly different from that promoted by the high-energy diet formulated on TAA basis (Table 3). This indicates that the combination high energy and DAA resulted in higher efficiency of feed use, that is, broilers fed this diet had higher weight gain with lower feed intake as compared to those fed lower energy level and DAA. It is possible that there was a lack of energy for tissue accretion, which led to higher intake in birds fed the lower energy diet in order to obtain the same calorie intake, resulting in worse feed conversion.

Diet formulations based on DAA resulted in better conversion of ME intake into weight gain (Table 2). This shows the higher efficiency of these diets as they allow a better transformation of ME intake into tissue synthesis and accretion. This is possibly related to a higher amino acid availability to use the available energy to synthesize muscle. Diets formulated with lower energy level $(2,900 \mathrm{kcal} \mathrm{ME} / \mathrm{kg})$ promoted a trend to a better conversion of ME intake into body weight. This suggests that the excess of ME intake caused by the diet with 3,200 kcal ME/kg was deposited as fat, which is metabolically less efficient than lean tissue accretion. Indeed, when abdominal fat deposition was evaluated, higher fat deposition was observed in birds fed diets with 3,200 kcal ME/kg (Table 4). It was also verified that the low-energy diet formulated on DAA basis promoted better conversion of ME into weight gain. The combination DAA and low energy possibly led to less ME available for fat deposition.

Formulation based on DAA did not influence carcass and breast yields, independent of the dietary energy level (Table 4). These results are consistent with Rostagno et al. (1995) and Dari \& Penz (1996), who found no differences in carcass yield.

Dietary energy levels had no influence on carcass and breast yield parameters. These data corroborate the results found by Nobre et al. (1994), who evaluated four energy levels and reported no significant differences in carcass yield.

When contrasts were evaluated, a significant difference was found for broilers fed a diet formulated on DAA (Table 4). Thus, the same hypothesis mentioned in the discussion on weight gain is also considered in this situation. The lower DAA level may have been compensated by the higher feed intake, and thus higher amino acid intake, in birds fed the low energy diet and DAA, that causes a deficiency of energy to synthesize tissues.

Diets formulated on DAA did not significantly influence abdominal fat deposition (Table 4). Dietary energy level significantly influenced abdominal fat percentage. High-energy diets resulted in higher abdominal fat deposition. This increase in abdominal fat percentage is probably related to the significant increase in metabolizable energy intake.

\section{CONCLUSIONS}

The formulation based on DAA is needed for diets containing protein sources that are not reliable in terms of amino acid digestibility.

Table 4 - Carcass and breast yield, abdominal fat deposition and efficiency of ME utilization (ME/body weight gain).

\begin{tabular}{|c|c|c|c|c|c|}
\hline Aminoacid (AA) & ME (kcal/kg) & Carcass (\%) & Breast (\%) & Abdominal fat (\%) & Efficiency of ME utilization \\
\hline Total & 2,900 & 83.68 & 18.67 & 2.05 & 6.509 \\
\hline Digestible & 2,900 & 84.85 & 18.58 & 2.23 & 6.405 \\
\hline Total & 3,200 & 84.24 & 18.63 & 2.75 & 6.939 \\
\hline Digestible & 3,200 & 84.41 & $\begin{array}{c}19.83 \\
\text { in effects }\end{array}$ & 2.68 & 6.359 \\
\hline Total AA & & 83.96 & 18.65 & 2.40 & 6.724 \\
\hline Digestible AA & & 84.63 & 19.20 & 2.45 & 6.382 \\
\hline $2,900 \mathrm{kcal} \mathrm{EM} / \mathrm{kg}$ & & 84.26 & 18.62 & 2.72 & 6.457 \\
\hline $3,200 \mathrm{kcal} \mathrm{EM} / \mathrm{kg}$ & & 84.33 & 19.23 & 2.14 & 6.649 \\
\hline \multicolumn{6}{|c|}{ Probability } \\
\hline AA & & 0.231 & 0.100 & 0.727 & 0.007 \\
\hline Energy & & 0.906 & 0.072 & 0.0001 & 0.103 \\
\hline AA*Energy & & 0.372 & 0.057 & 0.409 & 0.047 \\
\hline
\end{tabular}


Broilers fed low energy diets apparently obtain the adequate amount of energy by a higher feed intake. However, this is not sufficient to achieve optimal performance. On the other hand, when high-energy diets are fed, feed intake seems to be regulated by amino acid requirements, as birds have an apparent excessive metabolizable energy intake, which results in fatter carcasses. The interaction between digestible amino acids and higher energy level allows the full expression of the genetic potential for growth in broilers.

\section{REFERENCES}

Baker DH, Han Y. Ideal amino acid profile for chicks during the first three weeks of posthatching. Poultry Science 1994; 73:1441-1447.

Dari RL, Penz Jr. AM. The use of digestible amino acid and ideal protein concept in diet formulation for broilers. Poultry Science 1996; 75 (Supplement):67.

Fernandes RS, Zhang $Y$, Parsons CM. Dietary formulation with cottonseed meal on a total amino acid versus a digestible amino acid basis. Poultry Science 1985; 74:1168-1179.

Griffiths L, Lesson S, Summers JD. Fat deposition in broilers: Effect of dietary energy to protein balance, and early life caloric restriction on productive performance and abdominal fat pad size. Poultry Science $1977 ;$ 56:638-646.

Heartland Lysine. True digestibility of essential amino acids for poultry. Chicago. NAP. 1995.

Leeson S, Caston L, Summers JD. Broiler response to diet energy. Poultry Science 1996; 75:529-535.

National Research Council (NRC). Nutrient Requirements of Poultry. 9 ed., Washington, DC. National Academy Press. 1994. 155p.

Nobre RTR, Silva DJ, Fonseca JB, Silva MA, Lana GRQ. Efeito do nível de energia sobre a qualidade da carcaça de diferentes grupos genéticos de frangos de corte. Revista Brasileira de Zootecnia 1994; 24:603-614.

Rosebrough RW, Steele NC. Energy and protein relationships in the broiler. 1. Effect of protein levels and feeding regimens on growth, body composition, and in vitro lipogenesis of broiler chicks. Poultry Science 1985; 64:119-126.

Rostagno HS, Pupa JM, Pack M. Diet formulation for broilers based on total versus digestible amino acids. Journal of Applied Poultry Research 1995; 4:293-299.

SAS Institute. SAS ${ }^{\circledR}$ (Statistical Analysis System). User's Guide: Statistics. Cary, NC: SAS Institute Inc., 1998.

Sizemore FG, Siegel HS. Growth, feed conversion and carcass composition in females of four broiler crosses fed starter diets with different energy levels and energy to protein ratios. Poultry Science 1993; 72:2216-2228.
Summers JD, Slinger SJ, Ashton GC. The effect of dietary energy and protein on carcass composition with a note on a method for estimating carcass composition. Poultry Science 1965; 44:501-509. 


\section{Vem aí}

\section{MANEJO DE MATRIZES DE CORTE \\ $2^{a}$ Edição}

14 capítulos escritos por especialistas da área

\section{Editores:}

Marcos Macari

Ariel Antonio Mendes

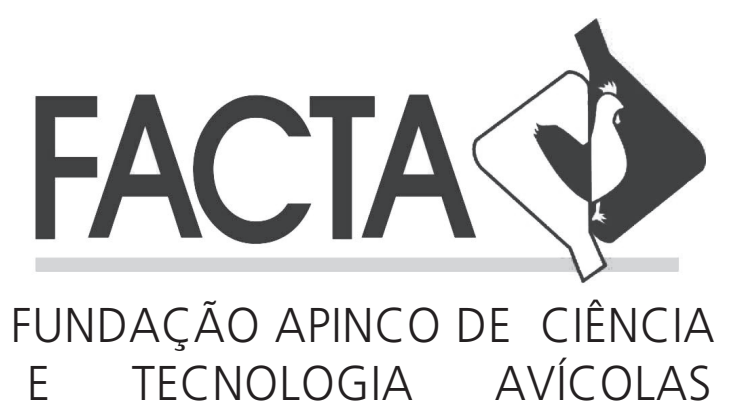

